\title{
Comparative Performance Assessment of Two Small Scale Irrigation Scheme in West Harerghe, Oromia Regional State, Ethiopia
}

\author{
Nade Nuru ${ }^{1, *}$, Mokenen Ayana², Najib Umer ${ }^{3}$ \\ ${ }^{1}$ Institute of Technology, Oda Bultum University, Chiro, Ethiopia \\ ${ }^{2}$ College of Civil Engineering and Architecture, Adama Science and Technology University, Adama, Ethiopia \\ ${ }^{3}$ College of Natural Resource and Environmental Science, Oda Bultum University, Chiro, Ethiopia
}

Email address:

nadenuru@gmail.com (N. Nuru)

${ }^{*}$ Corresponding author

\section{To cite this article:}

Nade Nuru, Mokenen Ayana, Najib Umer. Comparative Performance Assessment of Two Small Scale Irrigation Scheme in West Harerghe, Oromia Regional State, Ethiopia. American Journal of Management Science and Engineering. Vol. 5, No. 3, 2020, pp. $24-31$. doi: 10.11648/j.ajmse.20200503.11

Received: August 26, 2019; Accepted: March 25, 2020; Published: August 10, 2020

\begin{abstract}
This research was focused on assessing and comparing the performance of two small scale irrigation schemes: Homacho sogido and Jawis irrigation in west hararghe zone by using comparative indicator. Based on the collected data four (4) comparative indicator from the nine indicators indicated by IWMI's were selected for this study. The indicators used are output per cropped area, output per command area, and output per irrigation diverted, output per water consumed. The collected data are total yields, farm gate prices of irrigated crops, area irrigated per crop per season, crop types, production per season or per year, cropping pattern. The major crops grown in both schemes are Chat, Cabbage, Sorghum, Maize, Tomato, Soybean and Onion. The result of the analysis express that four agricultural indicators; output per cropped area, output per command area, output per water consumed and output per unit water supply are in the order of $16843.4 \mathrm{birr} / \mathrm{ha}, 19730.86$ birr $/ \mathrm{ha}, 2.23 \mathrm{birr} / \mathrm{m}^{3}, 4.24 \mathrm{birr} / \mathrm{m}^{3}$ and $24304.5 \mathrm{birr} / \mathrm{ha}, 38692.8 \mathrm{birr} / \mathrm{ha}, 3.29 \mathrm{birr} / \mathrm{m}^{3}$ and $4.28 \mathrm{birr} / \mathrm{m}^{3}$ for Jawis and Homacho sogido irrigation scheme, respectively. Excessive annual irrigation water was supplied by farmer in both scheme due to lack of knowledge on balancing crop water requirement and water diversion. This can be improved through training of farmer to balance crop water demand and water diversion. Homacho irrigation scheme could be benchmarked in the zone for water productivity and land productivity.
\end{abstract}

Keywords: Comparative Indicator, Performance Assessment, Small Scale Irrigation Scheme

\section{Introduction}

The world population is increasing at alarming rate resulting increasing demand for food and consequently percapita land and water resources are decreasing at alarming rate. Water resources are renewable, but these natural resources are limited unless, it used efficiently especially for agriculture. Food security in developing countries is aggravated by the rapid population growth and the consequent demand for food. To meet the demand for food, substantial investments in modifying existing irrigation scheme or establishing new ones will be necessary [10]. Irrigation is the highest water consumption sector which needs to be developed and managed in systematic manner to meet future agricultural water demand.

Water use and opposition among different users has been growing at more than twice the rate of population increase over the last century, leading to often conflicts among them [4]. Many large-scale irrigation schemes in least developed countries are out of the reach of smallholder farmers [15]. However, in these countries, small-scale irrigation is the primary donor to food security and developments in rural livelihoods. More beneficial of irrigation water allocation need a good evaluation of irrigation water allocation which need a good evaluation of irrigation of water demand, cropping pattern, designated area and project head operation 
[5].

Performance evaluation is the systematic analysis of an irrigation system and/or management based on measurements taken under field conditions and practices normally used and comparing the same with an ideal one [1]. The performance assessment by using performance indicator is a principal approach to improve the scheme performances [6].

Best irrigation management supported by realistic analysis techniques during drought season will help to make the right choice with respect to management aspect. The mismatch between the supply and demand in equitable distribution and the over irrigation of water consuming crops are the main constraints that are faced in implementation of the best irrigation water management [5]. In addition to internal performance indicator to evaluate the performance of the scheme, the International Water Management Institute (IWMI) suggests using minimum set of comparative indicators to assess hydrological, agronomic, economic and financial performance of irrigation system. Assessment of irrigation performances very essential while planning and verifying management strategies for various irrigation schemes whether large and small scale irrigation scheme.

Irrigated agriculture in Ethiopia comprises only a small fraction of total cultivated area. The estimated irrigation potential of Ethiopia is 4.3 million ha. From this potential currently developed area is 247,470 ha. This breaks into 138,339 ha $(55.90 \%)$ traditional schemes, 48,074 ha $(19.43 \%)$ modern small-scale irrigation and 61,057 ha (24.67\%) covered by modern medium and large-scale irrigation schemes [13]. Performance assessment of irrigation schemes studies have gained momentum since the late 1980s due to the common perspective that the land and water resources in irrigation schemes are not being properly managed [11]. Irrigation projects are widely studied, planed and implemented throughout Ethiopia. However, no attention is given to the monitoring and evaluation of the performance of already established irrigation schemes. The current irrigation development in Ethiopia is about $0.7 \mathrm{Mha}$, and the performance of the existing schemes is not well understood [7]. The majority of our people are settled in rural area, and the largest amount of income of the country is obtained from agriculture: Thus from development context to bring change the livelihood of the rural people and the overall development of the nation, we need to improve our agricultural sector [14].

However, in Ethiopia, especially West Harerghe Zone performance evaluation of irrigation scheme is rarely conducted. So, this study attempts to introduce the concept of comparative performance indicators in order to assess the comparative performance assessment of two small-scale irrigation scheme in the West Harerghe Zone.

\section{Material and Method}

\subsection{Description of the Study Area}

\section{location of Jawis and Homacho sogiddo scheme site}

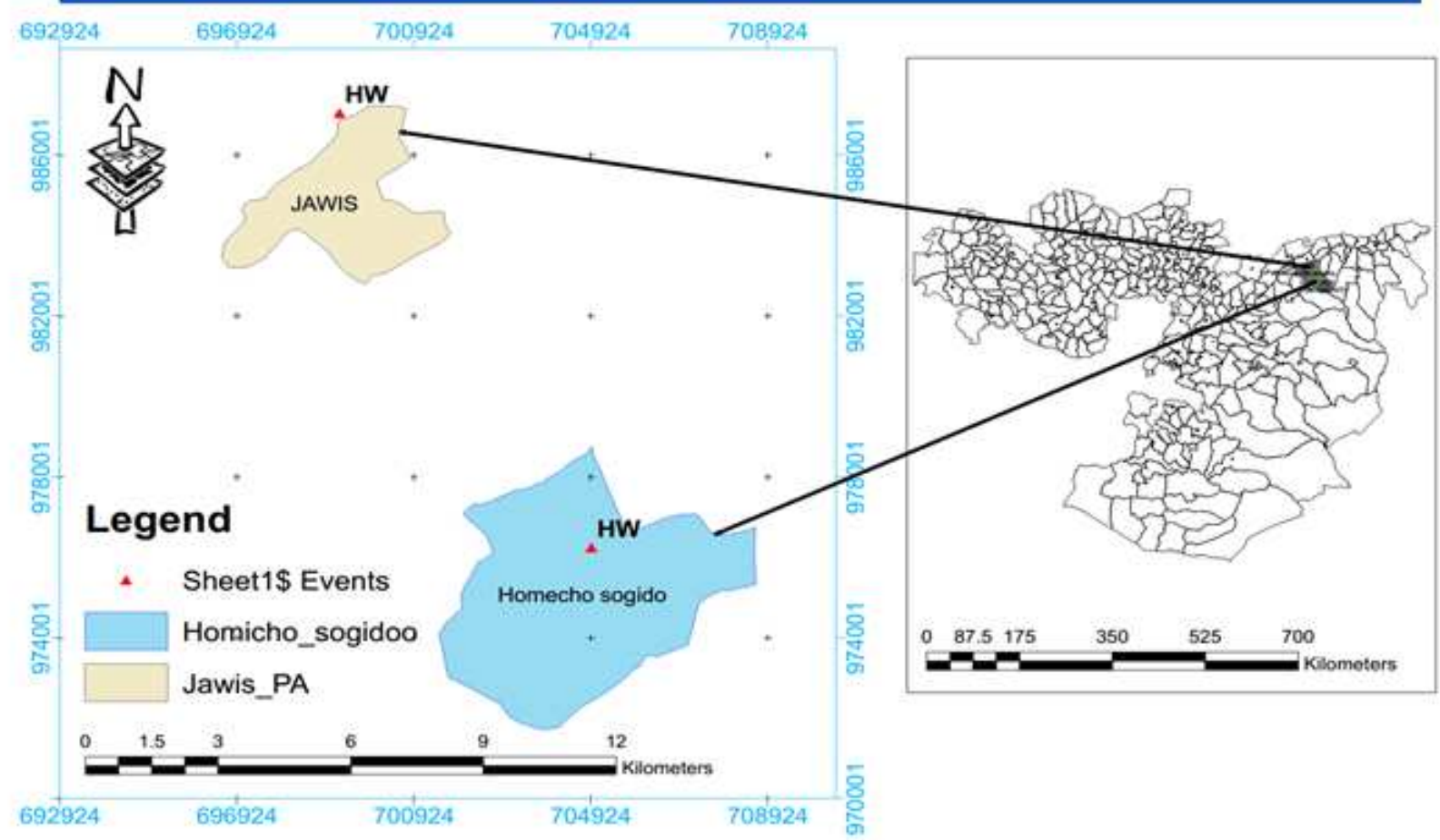

Figure 1. Location of Jawis and Homacho scheme with their headwork site. 


\subsection{Data Collection}

In order to achieve the objectives of the study secondary and primary data were used. These data were obtained from the West Harerghe irrigation development authority office, Oda Bulum and Gamachis woreda irrigation offices, nearest meteorological station and [3] paper. In addition, different project documents, project evaluation and completion reports was refereed.

\subsubsection{Primary Data Collection}

Total irrigation water diverted per season and actual capacity of main canal are the main primary that were collected through field observation and direct field measurement.

To calculate the total amount of water diverted to the total irrigated areas within a season, for the two irrigation schemes (Jawis and Homecho) the three inch parshall flume were installed in the main canal.

Measurement of depth of water by using three inch (3") parshall flume was taken two times per day at morning and afternoon to observe the change of water depth due to evaporation, siltation and other factor. The average water depth (ha) per day was made from the two measured depth at different time then by using the formula developed by [12] for standard three inch parshall flume the discharge capacity of the irrigation canal were calculated and the discharge formula was shown below:

$$
Q=0.99\left(h_{a}\right)^{1.55}
$$

Where $h_{a}=$ average depth of water in the irrigation canal (ft)

$$
Q=\operatorname{Discharge}\left(f t^{3} / s e\right)
$$

\subsubsection{Secondary Data Collection}

Secondary data were collected from the documents kept by the responsible bodies or officials at each irrigation project, Woreda irrigation Offices, and [3] paper and design document prepared by West Harerghe irrigation development authority offices.

The secondary data collected for this study were climatic, crop data, local prices of the harvested crop, irrigated cropped area and command area were collected from nearest meteorological station and West Harerghe Irrigation Development Authority office respectively.

\subsection{Data Analysis Method}

The analysis of data was carried out by using CROPWAT 8 model and Microsoft Excel work sheet for the analysis of agricultural productivity indicator.

\subsubsection{Comparative Performance Indicators}

The availability of secondary data are the main requirement for comparative indicators. Getting complete data required to calculate all the comparative indicators (the nine indicators) for each small-scale irrigation project was very hard. Hence, to compare the two-irrigation projects, one sets of comparative indicators such as: agricultural output indicator were applied with the available information collected and comparative analyses across the two schemes are made.

\subsubsection{Agricultural Output Indicators}

The four basic comparative performance indicators relate output to unit land and water were applied in this study. These "external" indicators provide the basis for comparison of irrigated agriculture performance, according to [9]. Where water is a constraining resource, output per unit water may be more important, whereas if land is a constraint relative to water, output per unit land may be more important. The outputs of agricultural production in this paper were based on local prices due to similarities of price and irrigation system for both schemes.

Output per unit irrigated cropped area (birr/ha)

It was computed the total value of agricultural production per unit of area under irrigation. The sum of the areas irrigated annually was considered.

$$
\text { Output per unit cropped area }\left(\frac{\text { birr }}{h a}\right)=\frac{\text { Annual Production }}{\text { Annual Irrigated cropped area }}
$$

Output per unit command area (birr/ha)

This is the value of agricultural production per unit of nominal or command area which can be irrigated.

$$
\text { Output per unit command area }\left(\frac{\text { birr }}{h a}\right)=\frac{\text { Annual production }}{\text { Command area }}
$$

Output per unit irrigation water supply (birr $\left./ \mathrm{m}^{3}\right)$

This states how well the total annual diverted irrigation water from a source is productive.

$$
\text { Output per unit irrigation water supply }\left(\text { birr } / \mathrm{m}^{3}\right)=\frac{\text { Annual production }}{\text { Diverted annual irrigation supply }}
$$

Output per unit water consumed (birr $\left./ \mathrm{m}^{3}\right)$

$$
\text { Output per unit water consumed }\left(\mathrm{birr} / \mathrm{m}^{3}\right)=\frac{\text { Annual production }}{\text { Volume of water consumed by ET }}
$$


Where,

Production is the output of the irrigated area in terms of gross or net value of production measured at local prices, Irrigated cropped area is the sum of the areas under crops, Command area is the nominal or design area to be irrigated, Diverted irrigation supply is the volume of surface irrigation water diverted to the command area, plus Volume of water consumed by ET is the actual evapotranspiration of crops.

$$
\mathrm{CWR}_{\text {crop-1 }} \times\left(\frac{\text { Area }_{\text {crop-1 }}}{\text { Total }_{\text {area }}}\right)+\mathrm{CWR}_{\text {crop-2 }} \times\left(\frac{\text { Area }_{\text {crop-2 }}}{\text { Total }_{\text {area }}}\right) \pm----+\mathrm{CWR}_{\text {crop }-\mathrm{n}} \times\left(\frac{\text { Area }_{\text {crop-n }}}{\text { Total }_{\text {area }}}\right)
$$

\section{Result and Discussion}

\subsection{Crop and Irrigation Requirement}

To calculate the agricultural productivity indicator for the analysis we need to calculate annual crop water demand and annual irrigation water demand of the major crops grown in

\subsubsection{Irrigation Demand and Crop Water Demand Determination}

The crop and irrigation water demand of the major crops grown in Hmacho and Jawis small scale irrigation schemes were determined by using CROPWAT 8 model.

The net crop and irrigation water requirement of the two season in the year of study were calculated by using equation (6).

Table 1. Result of CWR and IR of the Jawis irrigation scheme for two seasons in the year 2010E. C.

\begin{tabular}{|c|c|c|c|c|c|c|}
\hline \multirow{2}{*}{ Crop } & \multicolumn{3}{|l|}{$1^{\text {st }}$ season } & \multicolumn{3}{|l|}{$2^{\text {nd }}$ season } \\
\hline & Area (ha) & CWR (mm/season) & IR (mm/season) & Area (ha) & CWR (mm/season) & IR (mm/season) \\
\hline Sorghum & 12 & 303.4 & 30.1 & 12 & 303.4 & 30.1 \\
\hline Maiz & 13 & 307.9 & 4.1 & 13 & 307.9 & 4.1 \\
\hline Soybean & 15 & 255.9 & 28.1 & 15 & 255.9 & 28.1 \\
\hline Onion & 12 & 62.7 & 16.7 & 12 & 62.7 & 16.7 \\
\hline Pepper & 3 & 376.9 & 63.7 & 3 & 376.9 & 63.7 \\
\hline Tomato & 6 & 150.3 & 58.9 & 6 & 150.3 & 58.9 \\
\hline Cabbage & 4 & 207.3 & 60.1 & 4 & 207.3 & 60.1 \\
\hline Khat & 75 & 777.1 & 115.9 & & & \\
\hline Total & 140 & & & 65 & & \\
\hline
\end{tabular}

Table 2. Result of CWR and IR of Homacho irrigation scheme for two cropping season in the year 2010E. C.

\begin{tabular}{|c|c|c|c|c|c|c|}
\hline \multirow{2}{*}{ Crop } & \multicolumn{3}{|l|}{$1^{\text {st }}$ season } & \multicolumn{3}{|l|}{$2^{\text {nd }}$ season } \\
\hline & Area (ha) & CWR (mm/season) & IR (mm/season) & Area (ha) & CWR (mm/season) & IR (mm/season) \\
\hline Sorghum & 8 & 303.4 & 30.1 & 8 & 303.4 & 30.1 \\
\hline Maiz & 10 & 348 & 62.6 & 10 & 348 & 62.6 \\
\hline Soybean & 12 & 274.5 & 80.3 & 12 & 274.5 & 80.3 \\
\hline Onion & 11 & 62.7 & 16.7 & 11 & 62.7 & 16.7 \\
\hline Pepper & 15 & 376.9 & 63.7 & 15 & 376.9 & 63.7 \\
\hline Tomato & 15 & 150.3 & 58.9 & 15 & 150.3 & 58.9 \\
\hline Cabbage & 3 & 207.3 & 60.1 & 3 & 207.3 & 60.1 \\
\hline Sugar cane & 8 & 900.4 & 220.6 & & & \\
\hline Mango & 5 & 802.6 & 125.3 & & & \\
\hline
\end{tabular}

The net crop water requirement and net irrigation water requirement are determined for two irrigated cropping seasons of the two scheme in the year by using equation (8) and the result is presented in the Tables 3 and 4.

Table 3. Result of the NCWR and NIWR of the Jawis for the two irrigated seasons in the year of the study.

\begin{tabular}{lll}
\hline Season & NCWR (mm/season) & NIR $(\mathbf{m m} / \mathbf{s e a s o n})$ \\
\hline $1^{\text {st }}$ season (Oct-Feb) & 524.13 & 75.1 \\
$2^{\text {nd }}$ season (March-July) & 232.25 & 28.02 \\
Total & 756.38 & 103.12 \\
\hline
\end{tabular}

the schemes. In both Jawis and Homacho irrigation scheme no crop rotation was takes place from the first season to the next. That means the same crops were grown in the two irrigated cropping seasons on the same irrigated area. The result of the crop water requirement $(\mathrm{CWR})$ and irrigation requirement (IR) for the two irrigation scheme were presented in the Tables 1 and 2 respectively. 
requirement and irrigation water requirement of each crop grown Homacho irrigation scheme in both irrigated seasons were presented in Table 2. Then the net crop water requirement and Net irrigation water requirement result were calculated by using equation (6) and presented in Tables 3 and 4 for Jawis and Homacho irrigation scheme respectively. From Table 3 and 4 observed that net crop water requirement of Jawis scheme is greater than the net crop water requirement of Homacho scheme due to more perennial cropping intensity (Chat) in Jawis schemewhich is greater than perennial cropping intensity (Chat, Sugar cane, Mango and Banana) of Homacho irrigation scheme. Again from the Tables 3 and 4 observed that net irrigation water requirement of Homacho irrigation scheme is greater than that of Jawis irrigation scheme due to three additional perennial crop grown in the Homacho irrigation scheme.

\subsection{Performance Measurement}

To compare the two irrigation scheme four agricultural output indicator was used based on the available data in relation to land productivity and water productivity. The two used land productivity indicator are output per unit cropped area and output per unit command area and the two water productivity indicator are output per unit irrigation water supply and output per unit water consumed. The above four agricultural output indicator are used for comparing the scheme [7].

For the year 2009 and 2010E. C total agricultural production and outputs from the products at the local market price (ETbirr) were determined for the two irrigation scheme from the available data and presented in the Tables 5 and 6 respectively.

Table 5. Total yield and land coverage of Jawis and Homacho irrigation scheme for year 2009 E. C.

\begin{tabular}{|c|c|c|c|c|c|c|c|c|}
\hline \multirow[b]{2}{*}{ Crop } & \multicolumn{5}{|l|}{ Homacho } & \multicolumn{3}{|l|}{ Jawis } \\
\hline & Area (ha) & $\begin{array}{l}\text { Avg } \\
\text { (qt/ha) }\end{array}$ & yield & $\begin{array}{l}\text { Farm gate unit } \\
\text { price (birr/qt) }\end{array}$ & $\begin{array}{ll}\begin{array}{l}\text { Tot } \\
\text { (birr) }\end{array} & \text { income } \\
\end{array}$ & Area (ha) & $\begin{array}{ll}\text { Avg. } \\
\text { (qt/ha) }\end{array}$ & $\begin{array}{ll}\text { Tot } & \text { income } \\
\text { (birr) } & \\
\end{array}$ \\
\hline Cabbage & 18 & 15 & & 500 & 135000 & 26 & 12 & 156000 \\
\hline Sorghum & 20 & 4 & & 800 & 64000 & 20 & 5 & 80000 \\
\hline Maiz & 32 & 5 & & 700 & 112000 & 38 & 8 & 212800 \\
\hline Tomato & 16 & 5 & & 1,500 & 120000 & 12 & 9 & 162000 \\
\hline Onion & 12 & 10 & & 1,200 & 144000 & 18 & 9 & 194400 \\
\hline Banana & 5 & 6 & & 1,200 & 36000 & & & \\
\hline Sugarcane & 4 & 250 & & 1,000 & $1,000,000$ & & & \\
\hline Mango & 3 & 5 & & 1,800 & 27000 & & & \\
\hline Khat & 34 & 11 & & 1,500 & 561000 & 72 & 15 & 1620000 \\
\hline Total & 164 & 315 & & 11,400 & 2295000 & 208 & 62 & 2636400 \\
\hline
\end{tabular}

Table 6. Total yield and cropping pattern and land coverage of Jawis and Homacho irrigation scheme for the year 2010 E. C.

\begin{tabular}{|c|c|c|c|c|c|c|}
\hline \multicolumn{4}{|l|}{ Homacho } & \multicolumn{3}{|l|}{ Jawis } \\
\hline $\begin{array}{l}\text { Annual irrigated } \\
\text { area (ha) }\end{array}$ & $\begin{array}{ll}\text { Avg } & \text { yield } \\
\text { (qt/ha) } & \\
\end{array}$ & $\begin{array}{l}\text { Farm gate unit } \\
\text { price (birr/qt) }\end{array}$ & $\begin{array}{ll}\begin{array}{l}\text { Tot } \\
\text { (birr) }\end{array} & \text { income } \\
\end{array}$ & $\begin{array}{ll}\text { Annual } & \text { irrigated } \\
\text { area (ha) } & \\
\end{array}$ & Avg yield (qt/ha) & Tot income (birr) \\
\hline 6 & 15 & 750 & 67500 & 8 & 18 & 108000 \\
\hline 30 & 6 & 1800 & 324000 & 12 & 7 & 151200 \\
\hline 16 & 8 & 850 & 108800 & 24 & 10 & 204000 \\
\hline 24 & 6 & 1700 & 244800 & 26 & 11 & 486200 \\
\hline 22 & 9 & 1500 & 297000 & 24 & 16 & 576000 \\
\hline 20 & 10 & 750 & 150000 & 30 & 11 & 247500 \\
\hline 30 & 3 & 3500 & 315000 & 6 & 5 & 105000 \\
\hline 4 & 12 & 1500 & 72000 & & & \\
\hline 8 & 250 & 1100 & 2200000 & & & \\
\hline 5 & 12 & 1800 & 108000 & & & \\
\hline 34 & 16 & 1500 & 816000 & 75 & 14 & 1575000 \\
\hline 199 & 347 & 14650 & 4703100 & 205 & 92 & 3452900 \\
\hline
\end{tabular}

As observed in the Table 5 crop production for the year 2009 of the Homacho sogido and a Jawis irrigation scheme were $3682 q t$ and 2242qt respectively, which was obtained from the sum of $(\mathrm{col}-2 \times \mathrm{col}-3)$. The annual cropped area of Homacho sogido was 164 ha with annual gross income of 2295000 birr and the cropped area of the Jawis irrigation scheme was 208ha with annual gross income of 2636400birr in the year 2009E. c. The command area of the Jawis was 175ha and that of Homacho was 105ha. The cropped area of the two irrigation scheme was greater than the command area because all of the crops were cultivated twice per year except perennial crop. For the year 2010 the total annual crop production of Jawis was 2548qt with gross income of 3452900birr. The command area of the Homacho Sogido 
irrigation scheme was developed from 105 ha to $125 \mathrm{ha}$ in 2010E. c. Because of increment of discharge of the river according to the information gathered from woreda irrigation office.

Table 7. Command area, cropping area, irrigation water and yield of the Jawis and Homacho irrigation scheme.

\begin{tabular}{llll}
\hline Parameter & Year & Homacho & Jawis \\
\hline Command area (ha) & 2009 & 105 & 175 \\
Annual cropped area (ha) & & 164 & 208 \\
Water consumed $\left(\mathrm{m}^{3}\right)$ & & & \\
Irrigation supplied (m $\left.{ }^{3}\right)$ & & & \\
Production (birr) & & 2295000 & 2480400 \\
Command area (ha) & 2010 & 125 & 175 \\
Annual cropped area (ha) & & 199 & 205 \\
Water consumed (m $\left.{ }^{3}\right)$ & & 1428820 & 1550579 \\
Irrigation supplied (m $\left.{ }^{3}\right)$ & & 1099008 & 808704 \\
Production (birr) & & 4703100 & 3452900 \\
\hline
\end{tabular}

The two land productivity, comparative indicators were determined for Jawis irrigation scheme by using equation 2 and 3. The result of OPUIA and OPUCA are 11925birr/ha and $14173.7 \mathrm{birr} / \mathrm{ha}$ respectively. But the water productivity for the year 2009 was not calculated because of nonavailability of flow measurement data. The four agricultural productivity was determined for Jawis irrigation scheme in the year 2010. The result of OPUIA and OPUCA are 16843.4birr/ha and 19730.86birr/ha respectively.

Then to determine Water productivity indicator the depth of irrigation water diverted from the source were measured with three inch standard Parshall flumes. The measurement of the depth of water in the flume was taking place two times per day and the average depth was adopted. Then, based on these depths the discharge of the cropping seasons in the year of analysis were calculated by using equation (1) stated above. The continuous measurement for first cropping season (Oct-Feb) and the second cropping season (March- July) was undertaken. The consumed water is the actual crop evapotranspiration determined based on the parameter such as: cropping pattern, climate and rainfall data and soil of the command area. Then CWR and IR were determined by using FAO CROPWAT model version 8 . Then based on these value obtained from the model water productivity indicators were calculated for Jawis irrigation scheme by using equation 4 and 5. And the result of OPUIWS and OPUWC are $4.27 \mathrm{birr} / \mathrm{m}^{3}$ and $2.23 \mathrm{birr} / \mathrm{m}^{3}$.

With the same procedures, the values of agricultural indicator for Homacho sogido and Jawis were determined and summarized in the Table 8 for year 2009 and 2010E. C.

Table 8. Summary of the calculated agricultural indicator for the Jawis and Homacho scheme in the year 2009 and $2010 E$. C.

\begin{tabular}{|c|c|c|c|}
\hline Indicator & Year & Homacho & Jawis \\
\hline Output per unit irrigated area (Birr/ha) & \multirow{4}{*}{2009 E. C } & 13993.9 & 11495 \\
\hline Output per unit command area (Birr/ha) & & 21857 & 18260.6 \\
\hline Output per unit water consumed $\left(\mathrm{Birr} / \mathrm{m}^{3}\right)$ & & & \\
\hline Output per unit water supplied $\left(\mathrm{Birr} / \mathrm{m}^{3}\right)$ & & & \\
\hline Output per unit irrigated area (Birr/ha) & \multirow{3}{*}{ 2010E. C } & 24304.5 & 16843.4 \\
\hline Output per unit command area (Birr/ha) & & 38692.8 & 19730.86 \\
\hline Output per unit water supplied (Birr/m³) & & 4.28 & 4.24 \\
\hline
\end{tabular}

From the Table 8 the output per unit cropped area and output per unit command area of Homacho sogido was greater than that of Jawis in the year 2009E. c. Again from Table 8 in the year of 2010 also observed that output per unit irrigated area and output per unit command area of Homacho was greater than that of Jawis. This was due to larger cropping pattern in Homacho sogido irrigation scheme. In addition to similar crops grown in both scheme Homacho contain three additional high value perennial crops such as: Banana, Mango and Sugarcane, which did not grow in the Jawis scheme and comparatively more accessibility of irrigation water in Homacho. Also, as observed from the Table 8 the land productivity of both schemes were developed from year 2009 to 2010 this was due to the increment of market of the production and production in qt/ha but comparatively the Homacho scheme was better land productivity in both 2009 and 2010E. C. In case of water productivity indicator-output per unit irrigation water supply of the Homacho and that of Jawis are almost equal as observed from Table 8. Which implying that both of the scheme is good in effective utilization of their irrigation water. But comparatively Homacho irrigation scheme is better in effective utilization of water. And from the Table 8 the result of output per unit water consumed of Homacho irrigation scheme is greater than that of Jawis. This shows that the crops grown in Homacho scheme yield more compared to Jawis. The higher values of OPUIW and OPUWC of the Homacho irrigation scheme is due to more accessibility of water to farmer which make the farmer to grow more cropping pattern in the scheme. The results of performance with respect both the land and water productivity imply that Homacho scheme performs better and benchmark to the scheme in the zone.

\subsection{Evaluation of Performance Gaps}

From the comparative indicator used in this study the gap of the Homacho and Jawis irrigation scheme can be observed from the figure 2 of production indictor.

As observed from the figure 2 of production performance indicator in there was a considerable gap on land productivity 
indicator (OPUCA and OPUIA) between Homacho and Jawis irrigation scheme due to the variation in high value

cropping pattern grown in Homacho scheme.

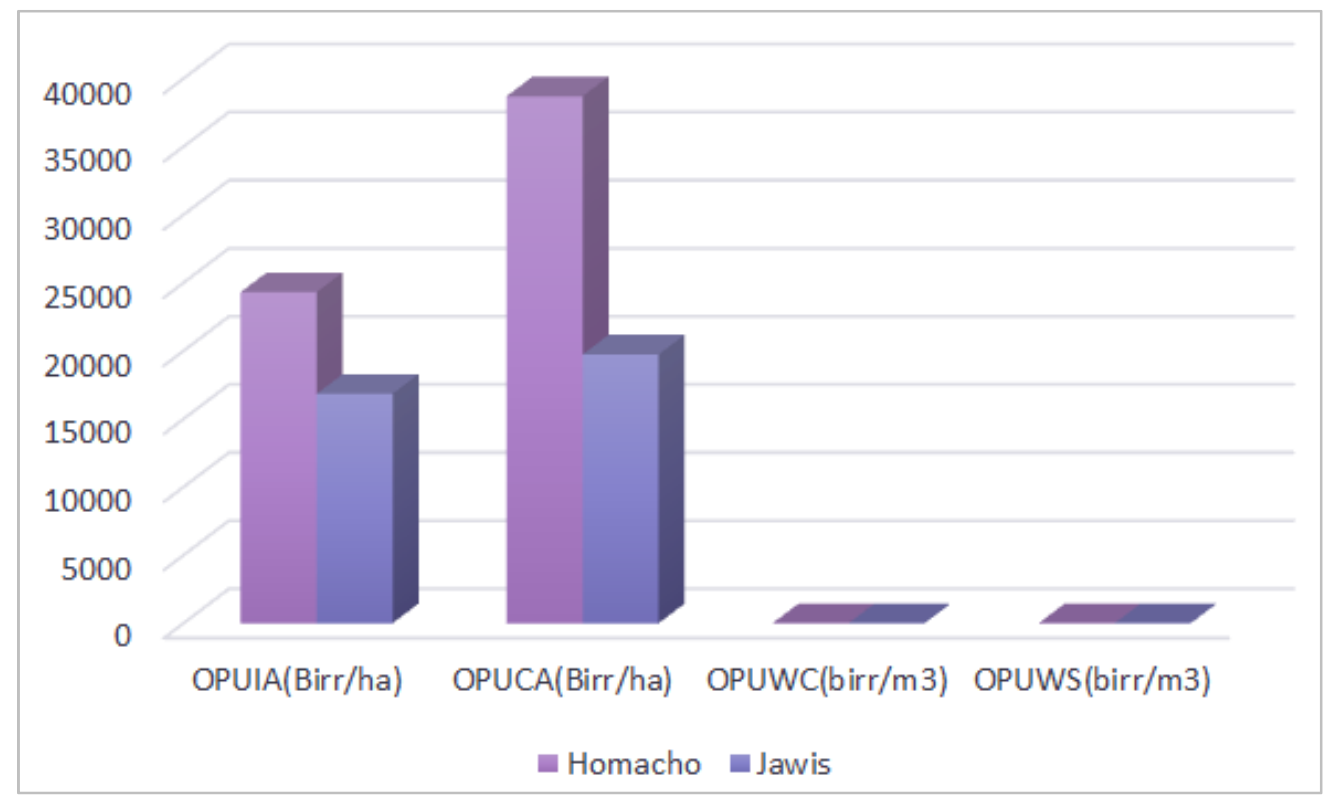

Figure 2. Land and water productivity indicator of Homacho and Jawis indicator.

As discussed in the literature there are four types of performance gaps existing in irrigation management according to [1] out of this the $3^{\text {rd }}$ and $4^{\text {th }}$ performance gaps observed in the scheme. The third gaps occurred when a difference arises between management targets and actual achievements which includes water delivery schedules and the fourth gaps is when management impacts is available this is a difference between what people think should be the ultimate effects of irrigation and what actually results. The farmers of the two schemes feels that excess irrigation water application would result in increased yield. And lack of proper irrigation and water delivery schedules are the reason for the above two gap.

\subsection{Improvement Options}

Excess application of irrigation water problem can be improved by preparing the water measurement device for the water user of the scheme in order to balance supply and demand of the water based on the crop water demand. And give the training for the farmers on the crop water requirement based on the major crop pattern in the scheme and on the procedure of using the instrument for measuring the amount of water which diverted into the field. Then RIS values is minimized by regulating the irrigation release from diversion structures to effectively use the water supply by adjusting the gate.

\section{Conclusion and Recommendation}

\subsection{Conclusion}

The comparative indicator used in this study is useful to compare different irrigation scheme to assess the degree of utilization of the available natural resources such as: land, water and component of the scheme.

The output per unit cropped area and output per unit command area of Homacho was greater than that of Jawis in the year 2009 and 2010. This was due to the larger cropping pattern and more accessibility of irrigation water to the farmers in the Homacho irrigation scheme as compared to the Jawis irrigation scheme. The OPUIA and OPUCA of both schemes was increased from 2009 to 2010 due to increasing of the market price of the product and production in quintal per hectare. The output per unit irrigation water supply and output per water consumed of the Homacho irrigation scheme is greater than that of Jawis irrigation scheme. Higher values of OPUIWS and OPUWC of the Homacho irrigation scheme indicates that Homacho irrigation scheme is better in effective utilization of the available land and water resources for irrigation.

In general, in 2009 and 2010 the Homacho sogido irrigation scheme was more productive due to additional high value perennial crops grown in the scheme in addition to major crop grown in both schemes. Therefore Homacho irrigation scheme could be benchmarked in the zone for both water productivity and land productivity.

\subsection{Recommendation}

1. Assigning DA and Office assistant for the water user association in order to improve water application for irrigation, especially on water diversion and overall irrigation water management.

2. Additional research should be done on the overall performance of the small scale irrigation scheme in the West Harerghe zone in order to assess internal and external performance of the scheme. 


\section{References}

[1] Ali M. H (2011). Technical performance evaluation of Byra Deep tube well a case study. Inst Eng Bangladesh.

[2] Douglas L. V., Juan A. S. 1999. Transfer of Irrigation Management services. Guideline: Irrigation and Drainage paper. No. 58. FAO, Rome.

[3] FAO. 1990. International workshop on capacity development of farm management strategies to improve crop-water productivity using AquaCrop. Training manual $1-5$ March. Bloemfontein. RSA.

[4] Imbenzi J. Serede, Benedict M. Mutua, James M. Raude (2014) A review for hydraulic analysis of irrigation canals using HEC-RAS model: A case study of Mwea irrigation scheme, Kenya. Irrigation and Drainage Systems 4: 283-312.

[5] Maatooq (2016). Evaluation of the hydraulic performance indicator for Al- Ibrahim for irrigation canal in the south of Iraq. Engineering and Technology Journal Vol-34, No-3-2016.

[6] Mamuye Tebeba and Mekonen Ayana (2015). Hydraulic Performance Evaluation of Hare Community Managed Irrigation Scheme, Southern, Ethiopia. International Research Journal of Engineering and Technology (IRJET). Volume: 02.

[7] Mekonen, A and Seleshi, B (2011) Comparison of irrigation performance based on management and cropping types. International Water management Institute for Nile Basin and East Africa.

[8] Molden D. J. and Gates T. K. (1990). Performance measures for evaluation of irrigation water delivery systems. Journal of irrigation and drainage engineering.
[9] Molden, D., Sakthivadivel, R., Perry, C. J., de Fraiture, C. and Kloezen, W. H. (1998). Indicators for comparing performance of irrigated agricultural systems. IWMI Research Report 20. New Delhi.

[10] Morya (2017). Performance evaluation of Irrigation scheme. Jawaharlal Nehru Krishi Vishwa Vidyalaya, Jabalpur.

[11] S. D. GORANTIWAR \& I. K. SMOUT (2005). Performance assessment of irrigation water management of heterogeneous irrigation schemes: A framework for evaluation. Water, Engineering and Development Centre, Loughborough University, Leicestershire, LE11 3TU, UK.

[12] Skogerboe, Gaylord V.; Hyatt, M. Leon; England, J oe D.; and Johnson, J. R aymond, "Measuring W ater with $\mathrm{P}$ arshall Flumes" (1966). Reports. Paper 83.

[13] Tilahun Haile and Paulos Dubale, 2004. Results to Date Future Plan of Research on Irrigation and its Impact. Workshop on Impact of Irrigation on Poverty and Environment, Workshop Proceedings, 26-30, April 2004, Addis Ababa.

[14] West Harerghe Irrigation Development Authority Office (2010). Design document of Homacho and Jawis Irrigation scheme (Unpublished).

[15] Zeleke, A., Amare, H., Hilmy, S., Teklu, E., Petra, S., Simon, L., and Dirk, H. (2015). Analysis of water delivery performance of small holder irrigation schemes in Ethiopia: Diversity and lessons across schemes, typology and reaches. LIVES working paper-15. Nairobi, Kenya: International Live stock Research Institute (ILRI). 